Acta Universitatis Wratislaviensis • No 4046

Literatura i Kultura Popularna XXVI, Wrocław 2020

https://doi.org/10.19195/0867-7441.26.22

\title{
Teresa Banaś-Korniak
}

ORCID: 0000-0001-8161-1580

Uniwersytet Śląski w Katowicach

\section{O komizmie w dwu staropolskich dramatach sceny popularnej: Tragedia żebracza nowouczyniona (1552) oraz Mięsopust abo Tragicocomaedia (1622)}

Słowa kluczowe: literatura staropolska, dramat karnawałowy, scena popularna

Keywords: Old-Polish literature, carnival drama, popular scene

Badacze literatury staropolskiej nieraz już zwracali uwagę, że tytuł utworu szesnasto- czy siedemnastowiecznego bywa niejednokrotnie mylący, to znaczy nie w każdym wypadku wskazuje na rzeczywisty gatunek literacki lub stylistyczną konwencję, do jakiej sięgał dawny autor. Tak też jest ze wskazanymi w tytule niniejszego szkicu dwoma anonimowymi tekstami dramatycznymi ${ }^{1}$, które z tra-

1 Pierwszy z utworów ukazał się jeszcze przed 1551 rokiem w drukarni Unglera, a zatytułowany był Tragedia żebracza, ale tekst tego wydania się nie zachował. Z edycji następnej, z roku 1552 (Tragedia żebracza nowouczyniona, drukowana u Łazarza Andrysowicza), dochowały się nieliczne fragmenty; w 1573 roku w Latomyślu prasy drukarskie opuścił przekład czeski, który w całości dotrwał do naszych czasów; na podstawie zachowanych polskich fragmentów z 1522 roku oraz posiłkując się czeską wersją, współczesny badacz Józef Magnuszewski zrekonstruował całość dramatu, stylizując język na szesnastowieczną polszczyznę. Informacje o tym w: J. Ziomek, Renesans, Warszawa 1995, s. 120. Zrekonstruowany przez Magnuszewskiego tekst przedrukowal Julian Lewański w tomie Dramaty staropolskie. Antologia, oprac. J. Lewański, M. Bokszczanin, t. 1, Warszawa 1959, s. 229-269. Wszystkie cytaty w niniejszym szkicu pochodzą z tego wydania. Z kolei utwór Mięsopust abo Tragicocomaedia na dni mięsopustne, nowo dla stanów rozmaitych zabawy podana został ogłoszony drukiem w 1622 roku (b.m.w.), ale — jak przypuszczał Czesław Hernas - najprawdopodobniej prezentowany był na scenie wcześniej, o czym informuje nieznany autor w (poprzedzającym tekst dramatu) wierszu, skierowanym do czytelnika. Zob. C. Hernas, 
dycją gatunkową tragedii niewiele mają wspólnego, a przez współczesnych literaturoznawców bywają określane bądź jako dramaty lub komedie „mięsopustne” (Jerzy Ziomek) $)^{2}$, bądź komedie „karnawałowe” (Czesław Hernas) ${ }^{3}$. Julian Lewański z kolei zalicza obydwa te utwory do grupy tak zwanych dramatów sowizdrzalskich, co nie jest sprzeczne $\mathrm{z}$ sądami Ziomka i Hernasa ${ }^{4}$. Za formułowaniem nazw gatunkowych nie podążały jednak prace w kierunku ustalenia konkretnych wyznaczników gatunkowych. Stan badań na temat gatunkowego zróżnicowania staropolskich komedii rybałtowskich jest dziś zatem niewielki. Literaturą dramatyczną w dawnej Polsce interesowali się już badacze z początków XX wieku. Wiktor Hahn zauważył: „Pierwszym utworem komicznym [...] w naszej literaturze jest Tragedyja żebracza"5. Treść utworu badacz ten omówił, stwierdził też, że komedia rybałtowska rozwinęła się z intermediów ${ }^{6}$.

Klasyfikacją komicznych dzieł sceny „teatru ludowego” w dawnej Polsce zajął się Stanisław Windakiewicz, który wprowadził nazwę „moralitety karnawałowe" dla utworów wystawianych na scenach staropolskich w okresie karnawału. Owe „moralitety” poklasyfikował według kryterium tematycznego na: pouczające o celach życia, paraboliczne, bachiczne i ,sztuki wykorzystujące motywy ze świata antycznego" ". Począwszy od lat pięćdziesiątych XX stulecia, badania nad staropolskim dramatem znacznie się rozwinęły, czego przykładem są rozległe

Barok, Warszawa 1976, s. 205. Wersję z roku 1622 przedrukował Karol Badecki w edycji Polska komedia rybałtowska, oprac. K. Badecki, Lwów 1931, s. 397-463. Wszystkie zawarte w niniejszej pracy cytaty pochodzą z tego wydania.

2 J. Ziomek, op. cit., s. 121-122.

3 C. Hernas, op. cit., s. 205-206.

4 J. Lewański, Dramat i teatr średniowiecza i renesansu w Polsce, Warszawa 1981, s. 360 389; por. autorskie hasło tegoż badacza: idem, Komedia, [hasło w:] Słownik literatury staropolskiej. Średniowiecze - renesans - barok, red. T. Michałowska przy udziale B. Otwinowskiej, E. Sarnowskiej-Temeriusz, Wrocław 1990, s. 326-327.

5 W. Hahn, Literatura dramatyczna w Polsce XVI w., Lwów 1906, s. 77.

${ }^{6}$ Ibidem, s. 76. O wykształceniu się komedii sowizdrzalskiej z intermediów pisze też J. Lewański, Studia nad dramatem polskiego odrodzenia, t. 1, Wrocław 1956, s. 242.

${ }^{7}$ S. Windakiewicz, Teatr ludowy w dawnej Polsce, Kraków 1902, s. 145-168. Podział Windakiewicza wydaje się intuicyjny; elementy tematyczne uznane za dystynktywne dla poszczególnych „odmian” występują bowiem we wszystkich utworach, których treść badacz omawia w obrębie poszczególnych podrozdziałów. Niemniej jednak dostrzeżenie moralitetowych tradycji przez uczonego jest cenne, aczkolwiek omawiane przez Windakiewicza teksty, wśród których są - uznawane za teksty „bachiczne” - Mięsopust abo tragicocomaedia, Dyjalog mięsopustny o Bachusie i inne, moralitetami typu średniowiecznego nie są, bo zawierają liczne motywy ludyczne, a oprócz postaci alegorycznych będących „nośnikami” kwestii moralistycznych (na przykład diabeł, Śmierć) w akcji biorą udział osoby fikcyjne (fictio personae) oraz „realne”: pijacy, bakałarze, żebracy, kosterzy i inni. Windakiewicz w obrębie rozdziału o sztukach „bachicznych” streszcza i omawia kilka krótkich rękopiśmiennych intermediów, co przemawia za tezą Hahna i późniejszym stwierdzeniem Lewańskiego, że mięsopustne przedstawienia komiczne sceny ludowej wykształciły się $\mathrm{z}$ intermediów. 
studia Juliana Lewańskiego ${ }^{8}$ i Jana Okonia ${ }^{9}$, ale w kwestii klasyfikacji gatunkowych przedstawień zapustnych nadal panował chaos. Lewański zwrócił uwage na charakterystyczną kompozycję widowisk mięsopustnych (wydarzenia przed pojawieniem się Bachusa i po jego przybyciu), ponadto jako pierwszy wysunął przypuszczenie, że komedie te były liczne w okresie staropolskim, ale zachowało się ich mało ${ }^{10}, \mathrm{w}$ przeciwieństwie do intermediów, których sporo przetrwało do czasów nam współczesnych ${ }^{11}$.

Kolejny badacz - Kazimierz Budzyk — podzielił komedie sowizdrzalskie na: jezuickie, dworskie i rybałtowsko-plebejskie ${ }^{12}$, co zanegował Stanisław Grzeszczuk, który wprawdzie gatunkowym zróżnicowaniem omawianych przedstawień się nie zajmował, ale — przyjmując kryterium „socjologiczne” do klasyfikacji tekstów sowizdrzalskich — uznał wszelkie dramaty rybałtowskie za wytwór tak zwanej literatury plebejskiej ${ }^{13}$, specyficznie rozumianej, a nazewnictwo „komedia plebejska” przejął za autorem Błazeńskiego zwierciadła Piotr Pirecki ${ }^{14}$.

8 Julian Lewański dokonał ,podziału” scen staropolskiego teatru na: dworskie, szkolne, sowizdrzalskie; określił „dowcip sowizdrzalski” przedstawień jako „spokojny, mało błyskotliwy”; Tragedię żebracza uznał za pierwszą polską komedię i wysoko ocenił jej wartość literacką; zob. idem, Studia nad dramatem polskiego odrodzenia..., s. 241-250 n.; idem, Wstęp, [w:] Dramaty staropolskie: antologia, oprac. J. Lewański, przyp. M. Bokszczanin, Warszawa 1959, s. 26-52 n.

9 Badając dramaty grywane na scenach jezuickich (głównie łacińskojęzyczne), badacz wyodrębnił wśród nich: moralitety, tragedie zapustne, dramaty hagiograficzne i epickie; zob. J. Okoń, Dramat i teatr szkolny: sceny jezuickie XVII w., Wrocław 1970, s. 191-222.

10 J. Lewański, Komedia..., s. 327.

11 Interludia, zarówno te wystawiane na scenach zamkniętych — „dworskich”, jak i te z kręgu sceny popularnej, przedstawiane na wolnym powietrzu (przy kościołach, jarmarkach) wykorzystują te same techniki wywoływania komizmu co wyszczególnione przeze mnie tragikomedie mięsopustne. Zasadnicza różnica między interesującą nas tragikomedią mięsopustną a intermedium polega na znacznym rozbudowaniu wątków akcji w tragikomedii i istnieniu wątków pobocznych (w interludium akcja jest najczęściej jednowątkowa, utrwala „migawkowe zdarzenia”); por. M. Mieszek, Intermedium polskie XVI-XVIII w. (teatry szkolne), Kraków 2007, s. 11-25 n.

${ }^{12}$ K. Budzyk, Komedia sowizdrzalska, „Pamiętnik Literacki” 43, 1952, z. 3-4, s. 814-866; idem, Trzy kręgi komedii sowizdrzalskiej, [w:] Studia z zakresu nauk pomocniczych i historii literatury polskiej, t. 2, Wrocław 1956, s. 271-314.

13 S. Grzeszczuk, Błazeńskie zwierciadło. Rzecz o humorystyce sowizdrzalskiej XVI i XVII wieku, Kraków 1994, s. 78-80 n.

14 Piotr Pirecki stosuje określenie „komedia plebejska” do wszystkich odmian staropolskiej komedii sowizdrzalskiej (wymiennie: rybałtowskiej); zdając sobie jednak sprawę z różnorodności gatunkowych, wskazuje na potrzebę klasyfikacji opartej na kryteriach formalnych, której zabrakło w dotychczasowych pracach Juliana Lewańskiego, Kazimierza Budzyka czy Stanisława Grzeszczuka. Pirecki pisze: „Bezwzględnie jednak termin »komedia plebejska« nie łączy się z komedią dworską (Marancyja czy Z chłopa król Piotra Baryki), gdyż obie sztuki powstały w odmiennym kulturowo kręgu niż stan plebejski oraz zostały wystawione na dworskich scenach" — idem, Polska komedia plebejska XVI i XVII w. Zarys monograficzny, Łódź 2008, s. 16, przyp. 1. Sprzeciw budzi dziś stosowanie kryterium socjologicznego przy badaniu literackich gatunków. Wielokrotnie bowiem w literaturze dawnej pojawiali się twórcy „nieszlacheccy”, na przykład Klemens Janicjusz, Szymon Zimorowic, którzy świadomie czerpali z konwencji poetyckich i retorycznych starożytności oraz nawiązywali do gatunków „klasycznych”. I odwrotnie, magnaci — Łukasz Opaliński 
Pierwszym autorem, który przy klasyfikacji dawnych gatunków komediowych uwzględnił terminologię zawartą w rękopiśmiennych poetykach sformułowanych XVII stulecia, był Tadeusz Bieńkowski. Badacz wyszczególnił mianowicie pośród dawnych scenicznych przedstawień między innymi: dialog, tragedię, komedię, intermedium, procesję i tragikomedię ${ }^{15}$. Z kolei Teresa Michałowska dogłębnie zbadała pojęcia gatunkowe ${ }^{16}$ dawnej teorii genologicznej dramatica poesis oraz rozpoznała definicje gatunków zapisane w ówczesnych poetykach, uwzględniające podział na: tragedię, komedię, tragikomedię i komikotragedię ${ }^{17}$. Jednocześnie zwróciła uwagę na znaczną rozbieżność między teorią sformułowaną a praktyką poetycką, postulując podjęcie prac nad tą ostatnią ${ }^{18}$.

Badająca komedie w polskim teatrze jezuickim XVIII stulecia, Irena Kadulska wspomniała, że w Rzeczypospolitej szlacheckiej początkowo grano w zapusty komedię, tragedię lub dialog, a ,wiek XVII wprowadził w spektakle karnawałowe refleksję nad marnościami świata (teatrum mundi), realizowane [...] w moralitetach, tragediach zapustnych, dramatach hagiograficznych i epickich" ${ }^{19}$. Kadulska rozwinęła temat wpływu komedii włoskiej dell'arte na jezuicką scenę szkolną, co doprowadziło do wykształcenia się w XVIII wieku „szkolnej komedii maski”20. O staropolskich „komediach zapustnych” pisał też Witold Wojtowicz, nie wdając się jednak w rozważania genologiczne. Autor pracy o „literaturze mieszczańskiej” rozpatrywał interesujące nas przedstawienia w kontekście koncepcji karnawału Dietza-Rüdigera Mosera i Wernera Mezgera, podkreślając funkcję dydaktyczną

(w utworze Coś nowego) czy Stanisław Herakliusz Lubomirski (w niektórych swych komediach) - nie odżegnywali się od stosowania poetyki sowizdrzalskiej (charakterystycznej dla staropolskiej literatury popularnej) do celów ekspresywnych. Usytuowanie określonych „typów” utworów w jednej grupie genologicznej powinno uwzględniać głównie kryteria formalne, w tym poetykę tekstów (pochodzenie autora może, ale nie musi wpływać na kształt gatunkowy tekstu), dlatego właśnie utwory Tragedia żebracza, Komedyja o mięsopuście, Marancyja, Z chtopa król, Dziewosłąb $d$ worski - z uwagi na podobieństwo wątków „karnawałowych”: maskaradę, współwystępowanie „moralitetowego pouczenia” i motywów ludycznych (gry, zabawy karnawałowe, pijaństwo, taniec, hazard, motyw małżeństwa), współistnienie scen smutnych i wesołych, pomyślne zakończenie można, jak sądzę, łączyć ze wspólnym genologicznym pojęciem i nazwą „tragikomedii mięsopustnej”. Charakterystyczna poetyka „świata na opak”, karykaturalne przejaskrawienia rzeczywistości przedstawionej, groteskowość, satyryczność, potoczne słownictwo niepozbawione wulgaryzmów — to wspólne cechy wielu gatunków z kręgu poetyki sowizdrzalskiej.

15 T. Bieńkowski, Gatunki dramatyczne w okresie staropolskim (wstępne klasyfikacje), „Ruch Literacki" 11, 1970, z. 2, s. 97.

16 Termin „pojęcie gatunkowe” Michałowska przejęła za teorią genologiczną Stefanii Skwarczyńskiej, ale zaznaczyła, że w poetykach staropolskich z góry zakładano „harmonijną zgodność pojęcia oraz przedmiotu genologicznego"; zob. T. Michałowska, Staropolska teoria genologiczna, Wrocław 1974, s. 22. Rozróżnienie nazw, pojęć i przedmiotów genologicznych zob. S. Skwarczyńska, Wstęp do nauki o literaturze, t. 3, Warszawa 1965, s. 35-37.

17 T. Michałowska, op. cit., s. 110-111 n.

18 Ibidem, s. 156.

19 I. Kadulska, Komedia w polskim teatrze jezuickim XVIII w., Wrocław 1993, s. 109.

20 Ibidem, s. 147-148. 
widowisk karnawałowych, a funkcja ludyczna była według badacza podporządkowana moralizatorstwu. Ponadto, powołując się na niemiecką badaczkę Annę Köhler, Wojtowicz stwierdza, że w Europie Zachodniej doby potrydenckiej komedie mięsopustne ewoluowały w kierunku tragikomedii ${ }^{21}$.

Próbę klasyfikacji tekstów komediowych dawnej sceny popularnej przeprowadził Piotr Pirecki, w którego pracy zauważamy pewną niekonsekwencję. Badacz zdaje sobie mianowicie sprawę, że pisarze rybałtowscy korzystali, podobnie jak autorzy dramatów sceny dworskiej, z tradycji poetyk antycznych, sięgali też po reguly gatunkowe wypracowane przez poetyki renesansowe ${ }^{22}$ (autor podaje nawet - za Elżbietą Sarnowską-Temeriusz — podział gatunków komediowych istniejący w siedemnastowiecznych poetykach rękopiśmiennych na komedię, tragikomedię, intermedia i komikotragedię), ale z faktu tego nie wyciąga badawczych wniosków ${ }^{23}$. Tworzy własną, niezależną od dawnej poetyki sformułowanej, terminologię dla „komedii plebejskich”, dzieląc je na: satyryczne, zapustne, parodystyczne moralitety karnawałowe oraz farsy ${ }^{24}$.

Zadaniem niniejszego szkicu nie jest monografia gatunku tragikomedii mięsopustnej, bo to wymagałoby obszerniejszego studium, ale wstępne jego rozpoznanie, uwzględniające poetykę sformułowaną renesansu i baroku. Moim celem jest wykazanie zarówno podobieństw, jak i różnic w budowie obydwu dramatów, co ma oczywisty wpływ na nieco odmienny charakter przedstawień komicznych, a także wskazuje na kierunek zmian dokonujących się w obrębie gatunku. Lektura tekstów komediowych dawnej sceny popularnej przekonuje, że do tej samej odmiany gatunkowej „tragikomedii mięsopustnych” można zaliczyć, oprócz wyszczególnionych w tytule szkicu utworów, również następujące dramaty: anonimową Komedyję o mięsopuście (powstałą około 1550 roku) ${ }^{25}$, Dziewostąba dworskiego (około 1620) ${ }^{26}$,

${ }^{21}$ W. Wojtowicz, Między literatura a kulturą. Studia o ,, literaturze mieszczańskiej” przełomu XVI i XVII wieku, Szczecin 2010, s. 284-318.

22 P. Pirecki, op. cit., s. 30.

23 Michał Głowiński już w latach osiemdziesiątych XX wieku postulował, aby przy rozpoznawaniu dawnych gatunków poetyckich uwzględniać zarówno praktykę poetycką, jak i teorię sformułowaną i gatunkowe reguły. Te ostatnie - przy obowiązywaniu zasady estetycznej imitatio $\mathrm{w}$ epoce staropolskiej były istotne (zwłaszcza w baroku, kiedy teoria była w stosunku do praktyki wtórna); zob. idem, Gatunek literacki i problemy poetyki historycznej, [w:] Genologia polska. Wybór tekstów, wyb., oprac. i wstęp E. Miodońska-Brookes, A. Kulawik, M. Tatara, Warszawa 1983, s. 85-87 n.; analogiczne stanowisko zajmuje T. Michałowska, op. cit., s. 152-156.

24 Podział ten nie jest potwierdzony pogłębioną analizą genologiczną. Badacz omawia w poszczególnych rozdziałach jednostkowe utwory, przyporządkowując je do różnych, nazwanych przez siebie „odmian”, ale z tych omówień wynika, że wszystkie rozpatrywane w kilku podrozdziałach teksty zawierają analogiczne elementy moralizatorskie, satyryczne, parodystyczne, farsowe; zob. P. Pirecki, op. cit., s. 45-112.

25 Zob. Dramaty staropolskie. Antologia..., s. 593-623.

26 M. Pochlebca, Dziewostab dworski mięsopustny ucieszny, [w:] Polska komedia rybałtowska..., s. 353-386. Nazwisko autora jest najprawdopodobniej pseudonimem. 
Marancyję $(1620)^{27}$, a także tekst Piotra Baryki Z chtopa król $(1637)^{28}$. Wybór do analizy dwu utworów - Tragedii żebraczej (około 1550) i Mięsopustu (1622) jest umotywowany nie tylko wyrazistością cech gatunkowych, ale też zarówno względami chronologicznymi (Tragedia żebracza jest uznawana przez badaczy za pierwszy polski utwór komediowy ${ }^{29}$, a Mięsopust — za dojrzałą formę komedii rybałtowskiej ${ }^{30}$ ), jak i wartością estetyczną: obydwa odznaczają się regularną kompozycją, walorami języka i stylu.

Wtórna w stosunku do literackiej praktyki Poetyka praktyczna z 1648 roku w rozdziale o poesis dramatica wskazywała na funkcjonujące w ówczesnym literackim obiegu gatunki „tragikomedii” oraz „komikotragedii”, a także definiowała je:

Tragicomoedia est actio poetica constans traicis et comicis rebus [...] comicotragoedia est actio poetica comicis et traicis rebus constans [...] („Tragikomedia jest poetycką akcją, składającą się z tragicznych i komicznych elementów [...] komikotragedia jest poetycką akcją, składającą się z komicznych i tragicznych elementów") ${ }^{31}$.

Pierwszą z wymienionych - tragikomedię, mającą pomyślne - a zatem spokojne i godne — zakończenie, nieznany autor poetyki ,praktycznej” uznawał za odmianę komedii, w czym zgadzał się ze swym poprzednikiem - Jakubem Pontanusem, teoretykiem późnorenesansowym ${ }^{32}$. Zarówno w „komikotragedii”, jak i „tragikokomedii” wolno było, według uczonego siedemnastowiecznego, wprowadzać do akcji postaci dostojne obok tych pospolitych, a także mieszać z sobą dowolnie sceny wesołe i smutne.

W dwu wskazanych dramatach akcja ma finał raczej pomyślny, trudno go jednak nazwać „szczęśliwym zakończeniem”. Nikt znaczący nie umiera i nie doznaje krzywdy, a żaden bohater nie jest tak szlachetny, aby jego losy miały u widzów (nie tylko dawnych, ale i współczesnych) wzbudzać poruszenie czy — ujmując rzecz w terminologii Arystotelesa — wywoływać u odbiorców „litość i trwogę,"33 (IX 1452a, 1-5). Zatem — wedle teorii dawnej — uchodziły zapewne za odmiany komedii. Rodowód gatunkowy obydwu utworów, jak wspomniano wcześniej, łączy się z tradycją widowisk karnawałowych, które w dawnej Rzeczypospolitej szlacheckiej nawiązywały do niemieckich dramatów mięsopustnych (Fastnachtspiele $)^{34}$. Charakter tych widowisk, wystawianych często na tak zwanych scenach ludowych,

27 Anonim, Marancja, [w:] Polska komedia rybaltowska..., s. 465-494.

28 P. Baryka, Z chtopa król, [w:] Polska komedia rybaltowska..., s. 583-623. O motywie literackim i szekspirowskich powinowactwach komedii Baryki zob. D. Chemperek, ,_Z chtopa król” Piotra Baryki - historia, Shakespeare i tradycja literacka, „Pamiętnik Teatralny” 52, 2003, z. 1-2, s. 5-34.

29 W. Hahn, op. cit., s. 77; J. Lewański, Dramat i teatr..., s. 213.

30 S. Windakiewicz, op. cit., s. 158-160.

31 Poetica practica anno domini 1648, cyt. za: V.I. Riezanov, K isstorii russkoj dramy. Ekskurs w oblast' tieatra jezuitov, Niežyn 1910, s. 368 (tłumaczenie własne).

32 J. Pontanus, De comoedia; De tragoedia, [w:] idem, Poeticarum Institutionum libri III, Ingolstadii 1597, starodruk Biblioteki Jagiellońskiej, sygn. BJ 59045 6/I, s. 87-88.

33 Por. Arystoteles, Poetyka, przeł. i oprac. H. Podbielski, Wrocław 1983, s. 29.

34 J. Ziomek, op. cit., s. 121. 
czyli na otwartej przestrzeni, na przykład w trakcie odpustu lub jarmarku, a niekiedy też w karczmach ${ }^{35}$, musiał jednak na naszym rodzimym gruncie znacznie ewoluować w ciągu kilkudziesięciu lat, które dzielą powstanie i druk dwu wskazanych tekstów (pierwszy z nich został napisany w okresie dojrzałego renesansu, drugi — w baroku), albowiem znacznie różnią się one od siebie zarówno kompozycją, jak i kreacją bohaterów oraz sytuacji, które są źródłem komizmu. Porównanie akcji obydwu utworów dowodzi, że zarówno odbiorcy popularnych przedstawień szesnastowiecznych, jak i siedemnastowiecznych preferowali komizm oparty na parodii utartych schematów i wzorców, na kontraście wobec ówczesnych norm społecznych, obyczajowych, religijnych, a także na degradacji (śmieszyło bowiem poniżanie przez autorów komedii osobistości uznanych za godne i poważane, bawiło też wykazywanie ich ułomności, nałogów i przywar) ${ }^{36}$.

Przypomnę, że wprawdzie pojęcia komizmu dawne poetyki sformułowane nie znały, to jednak pojawiała się refleksja teoretyczna, która uogólniała niektóre aspekty przedmiotu komicznego. W teorii renesansowej zjawisko komizmu ujmowano za pomocą różnego nazewnictwa, najczęściej pojawiające się określenia to: „trefność”, „śmieszność”, urbanitas (co miało oznaczać „żart wytworny”), argutia (w thumaczeniu na język polski — „bystrość”, „dowcip”), lepor (wdzięk, dowcip). W szesnasto- i siedemnastowiecznych rozważaniach na wskazany temat sięgano najczęściej do autorytetu Arystotelesa (oraz jego definicji wyrażonej

35 J. Lewański pisał: „Widownię teatru rybałtowskiego zapełniał różnoraki tłum, oglądano go $\mathrm{w}$ bogatych domach kmiecych z wielkimi piekarniami i izbami czeladnymi, w domach mieszczańskich, w zajazdach i gospodach" - idem, Dramat i teatr..., s. 382.

36 Próba dokładniejszego wykazania różnic w odczuwaniu komizmu przez ludzi nam współczesnych i tych z czasów dawnych (na przykład Polaków z wieków XVI i XVII) nie może się powieść. Badacze komizmu od dawna bowiem zwracają uwagę na trudności w dookreśleniu tej kategorii estetycznej, mnożenie terminów i rozbudowywanie klasyfikacji. Juliusz Kleiner pisał: „Kryterium wyróżniającym zjawiska komiczne od innych nie jest struktura zjawisk (jak w przypadku tragizmu), lecz odrębne od nich — należące do innej sfery — reakcje psychiczne czy psychofizyczne". Usiłowania „skonstruowania” jednolitego określenia komizmu są więc daremne, bo nie uwzględniają subiektywnych odczuć jednostek: nawet w tej samej formacji kulturowej to, co dla danej jednostki jest śmieszne, dla innej wcale takie być nie musi. Zob. idem, Studia z zakresu teorii literatury, Lublin 1961, s. 77-79 n. Teoretycy komizmu wskazywali na wiele obiektywnych i subiektywnych okoliczności motywujących jego przeżycie, między innymi odczucie wyższości, przewagi i bezpieczeństwa obserwatora dystansującego się wobec komicznego obiektu; zaskoczenie odbiorcy i przemiana jego postawy na skutek kontrastu między początkowym nastawieniem a ostatecznym rozwiązaniem sytuacji; ujawnienie oczywistej niedorzeczności, absurdu, niecelowości; ujawnienie sprzeczności pomiędzy prawdą a pozorem; zobrazowanie rozmaitych form automatyzacji i mechaniczności będących przeciwwagą dla niepodlegającego schematyzacji życia. Zob. m.in. B. Zawadzki, Przegląd krytyczny ważniejszych teoryj komizmu, „Przegląd Filozoficzny” 1929, z. 1-2, s. 17-59; J. Trzynadlowski, Komizm, „Prace Polonistyczne” 1952, seria 10, s. 379-392; J. Ziomek, Komizm - spójność teorii i teoria spójności, [w:] idem, Powinowactwa literatury. Studia i szkice, Warszawa 1980, s. 319-354; M. Wallis, O przedmiotach komicznych, [w:] idem, Przeżycie $i$ wartość. Pisma z estetyki i nauki o sztuce (1931-1949), Kraków 1968, s. 297-303. 
w V księdze Poetyki ${ }^{37}$, V 1449a, 34-35; i w III księdze Retoryki ${ }^{38}$, III, 1419b); do źródeł rzymskich (Ars poetica Horacego) oraz do poetyk późniejszych: Donatusa (IV wiek n.e.), Diomedesa (IV wiek n.e.), Jana z Garlandii (XIII wiek) i innych ${ }^{39}$. W wywodach teoretycznych przeważały dwa stanowiska dotyczące istoty komizmu, mianowicie wiązano go albo z kontrastowością, albo z degradacją jakiegoś obiektu, w czym niewątpliwie można się dopatrzyć wpływów poglądów Stagiryty na rozpatrywane zjawisko. Na gruncie rodzimym najszerzej zagadnienie trefności rozwinął Łukasz Górnicki w Księdze wtórej swego Dworzanina polskiego ${ }^{40}$. Wieki dawne koncentrowały się głównie na teorii fabuły lub akcji komicznej, teorii bohatera komicznego, a także na języku i stylu sprzyjających efektom komicznym ${ }^{41}$. Skupię się zatem głównie na tych trzech aspektach budowy dwu wskazanych dramatów.

Zgodnie z zaleceniami ówczesnej teorii genologicznej obydwa utwory poprzedzone są ,argumentem”, czyli wypowiedzią postaci, która zarysowuje krótko temat i treść prezentowanych widzom wydarzeń. Tekst wcześniejszy, napisany przez nieznanego autora ${ }^{42}$ w epoce renesansu, pod tytułem Tragedia żebracza, charakteryzuje się akcją prostszą niż utwór z 1622 roku, opierającą się na konflikcie między bogatym kupcem a bandą żebraków. Do kłótni zakończonej pobiciem kupca doszło w podmiejskiej karczmie o nazwie Potok, sytuowanej w pobliżu Częstochowy. Mniej wyraźne wydaje się także pokrewieństwo tekstu szesnastowiecznego $\mathrm{z}$ widowiskami mięsopustnymi, gdyż czas akcji dramatu nie jest jasno dookreślony, ale związany z ucztą i tańcami żebraków, którzy postanowili urządzić sobie zabawę weselną. Para łachmaniarzy postanowiła bowiem połączyć się

37 „Komedia, jak stwierdziliśmy, jest naśladowaniem ludzi gorszych, lecz bynajmniej nie w znaczeniu wszystkich ich wad, a tylko w zakresie śmieszności, która jest częścią brzydoty. To, co śmieszne, jest przecież związane z jakąś pomyłką lub z bezbolesnym i nieszkodliwym oszpeceniem, czego wymownym przykładem, żeby nie szukać daleko, jest brzydka i powykrzywiana, lecz nie wyrażająca bólu, maska komiczna" - Arystoteles, Poetyka..., s. 14-15.

38 Arystoteles, Retoryka, przeł., wstęp i kom. H. Podbielski, [w:] idem, Dzieła wszystkie, t. 6. Polityka, Ekonomika, Retoryka, Retoryka dla Aleksandra, Poetyka, zachęta do Filozofii, ustrój polityczny Aten, List do Aleksandra Wielkiego, Testament, Warszawa 2001, s. 302-478.

39 T. Michałowska, Staropolska teoria genologiczna..., s. 101-111; eadem, Komizm, [hasło w:] Stownik literatury staropolskiej..., s. 330-335.

40 Ł. Górnicki, Dworzanin polski, oprac. R. Pollak, t. 2, Wrocław 2004, s. 199-290 n. O teorii „trefnowania” Łukasza Górnickiego zob. S. Dobrzycki, Humor i dowcip w Polsce XVI wieku, [w:] idem, Z dziejów literatury polskiej, Kraków 1907, s. 109-147; M. Wojtkowska-Maksymik, „Gentiluomo cortigiano” $i$, dworzanin polski”. Dyskusja o doskonałości człowieka w „Il Libro del Cortigiano” Baldassarra Castiglionego i w „Dworzaninie polskim” Łukasza Górnickiego, Warszawa 2007, s. 167-168.

41 T. Michałowska, Staropolska teoria genologiczna..., s. 101-106 n.; eadem, Komizm..., s. 330 .

42 Autorzy kompendium bibliograficznego Nowy Korbut uważają, że potencjalnym autorem mógł być Marcin Bielski; zob. Bibliografia Literatury Polskiej Nowy Korbut. Piśmiennictwo staropolskie, oprac. zespół pod kierownictwem R. Pollaka, t. 1, Warszawa 1963, s. 266. 
węzłem małżeńskim, więc reszta grupy chciała ten radosny fakt uczcić. Zrazu trudno dopatrzyć się w Tragedii żebraczej przedstawień maskaradowych, niemniej jednak za maskaradę można uznać zrzucenie przez żebraków łachmanów i przystrojenie się w bogate, odświętne szaty. Z kolei w dramacie siedemnastowiecznym obserwujemy już więcej różnych postaci w maskach.

Przyjęcia weselne w dawnej Rzeczypospolitej organizowano zazwyczaj po Bożym Narodzeniu, a przed Środą Popielcową ${ }^{43}$, możemy się zatem domyślać, że akcja Tragedii żebraczej rozgrywa się w okresie mięsopustnym. Sam fakt urządzenia wystawnej uczty i tańców przez grono nędzarzy już w informacji wygłaszającego „argument” Prologusa wydaje się pewnym odstępstwem od normy ${ }^{44}$ (,Wszystko zuchwałe żebraki / Zgromadzone jako szpaki. [...] Godowali, dobrze pili. [...] Wesele sobie stroili”45), co zaskakuje, ale i śmieszy. Śmiech wywoływany jest przez kontrast między wyobrażeniem stereotypowym żebraka — w łachmanach, ułomnego, chorego, smutnego i głodnego - a literacką kreacją grona osobników zdrowych, radosnych, sytych, a co więcej - pełnych wigoru i skocznych w tańcu. Stać ich nie tylko na piękne i wystawne szaty, w które się wystroili, lecz także są w stanie zapłacić karczmarzowi za kosztowną biesiadę. Mało tego, kulawy okazał się całkiem sprawny w tańcu, a ,jednooki / Przeróżne wyprawia skoki"46. Inni się śmieją, uprawiają hazard, grając za pieniądze w kości i karty; mężczyźni wesoło zabawiają się ze swymi kobietami: „Tamten jak błazen kugluje, / Ów zaś się z babą miłuje, / A raźniej niż zdrowi skaczą, / Cisnąwszy torbę żebraczą. / Inszy w koście, w karty grają, / Chocia ręce chrome mają"47.

Atmosfera zabawy nie podoba się przybyłemu do karczmy na spoczynek Kupcowi, który wygłasza pod adresem ucztujących oskarżycielską przemowę. Wymiana zdań między przedstawicielami żebraków a Kupcem sprowadza się do wzajemnych inwektyw i wychwalania statusu własnego stanu. Kupiec nazywa swych adwersarzy ,podpalaczami”, zarzuca im między innymi okłamywanie i zwodzenie ludzi w celu wyłudzania pieniędzy, fałszywą pobożnośćc ${ }^{48}$ oraz służenie za pieniądze „bezbożnym” Turkom. Żebracy z kolei lekceważą Kupca i grożą mu pobiciem, a pogróżki wypowiadane przez włóczęgów pod adresem nobliwego reprezentanta stanu mieszczańskiego ${ }^{49}$, mającego poczucie wyższości wobec swych antagonistów, musiały śmieszyć ówczesną ludową widownię, albowiem osoba szacowna zostaje zdegradowana i jest poniżana przez przedstawicieli najniższej warstwy społecznej. Eksponowanie komizmu poprzez kontrastowe zesta-

43 Por. J.S. Bystroń, Rok obrzędowy, [w:] idem, Dzieje obyczajów w dawnej Polsce. Wiek XVIXVIII, Warszawa 1976, s. 46-52 n.

44 Por. uwagi teoretyków o komizmie będącym odstępem od określonej normy, wynikającym z niedorzeczności i absurdu; zob. B. Zawadzki, op. cit., s. 26, 39-40 n.

45 Tragedia żebracza nowouczyniona..., s. 231. Zob. przyp. 1.

46 Ibidem, s. 236.

47 Ibidem.

48 Ibidem, s. 244.

49 Ibidem, s. 248. 
wienia oraz zamianę społecznych ról było charakterystyczne dla mięsopustnych widowisk $^{50}$. Sytuacja zaostrza się, kiedy jeden z żebraków, o imieniu Wyrwant, odpowiada na inwektywy Kupca i wygłasza ciąg oskarżeń pod adresem stanu kupieckiego: wśród ludzi tej profesji, jak twierdzi, jest wielu fałszerzy i oszustów, za co niechybnie znajdą się w piekle.

W akcji dramatu rysuje się i narasta konflikt, będący efektem nawarstwiania się coraz cięższych zarzutów padających pod adresem obydwu skłóconych stron. Dochodzi nawet do tego, że posądzają się wzajemnie o czary, a więc i konszachty z siłami nieczystymi, co powoduje, że oburzenie zarówno Kupca, jak i jego antagonistów narasta, w związku z czym bogacz krzyczy: „Cóż to ja słyszę nowego od żebractwa nikczemnego"51. Obustronne obrzucanie się inwektywami doprowadza do kulminacji kłótni, która kończy się w momencie uderzenia Kupca przez jednego z żebraków, a to daje początek rękoczynom. Większość łachmaniarzy rzuca się z pięściami na bogacza. Sam moment pobicia, prezentowany na ludowej scenie, musiał być dla ówczesnych odbiorców komiczny, bo — jak informują didaskalia — w bójkę oprócz mężczyzn angażują się zacietrzewione żebraczki, przy czym rekwizyty proszalnych dziadów: szczudła, laski, kije stają się narzędziami walki. Panuje ogólny rozgardiasz, a to przywodzi na myśl kłębowisko irracjonalnie zachowujących się ludzkich kukiełek ${ }^{52}$. Kobiety próbują wyrwać Kupcowi mieszek z gotówką i sypią mu piasek w oczy. Bitwa Kupca z żebraczkami o torebkę z pieniędzmi to scena komiczna, a źródłem komizmu jest tu niegodna postawa bogacza, który wdał się w szarpaninę z nędzarkami.

Dostojnemu mieszczaninowi udaje się w końcu „,Z wielgim trudem”,53 uciec przed oprawcami. Poniżenie, a tym samym śmieszność osoby pobitego nieszczęśnika (który nie doznał w przedstawionym incydencie większej krzywdy oprócz kilku siniaków i guzów) pogłębia się, kiedy w akcie III przychodzi on ze skargą do przywódcy bandy, która go pobiła, z żądaniem rekompensaty za poniesione szkody moralne i materialne. Herszt włóczęgów, wysłuchując racji obydwu stron konfliktu, wydaje wyrok absurdalny, chociaż z góry przewidywalny. Kupiec mianowicie nie uzyska żadnego zadośćuczynienia za poniesione szkody, żebrak bez oka ma się z bogaczem pogodzić i za karę zostać bez oka, beznogiemu zaleca się, aby za karę został bez nogi, a osobnika bez ręki skazuje się na pozostanie bez tej kończyny. Ludową widownię śmieszył zapewne nie tylko absurdalny wyrok przywódcy żebraków, ale też naiwna postawa Kupca, który od szefa włóczęgów oczekuje sprawiedliwości.

${ }^{50}$ Zwrócił na ten fakt uwagę J. Lewański, omawiając problematykę Tragedii żebraczej; zob. idem, Dramat i teatr..., s. 217 n.

51 Tragedia żebracza nowouczyniona..., s. 252.

52 Zjawisko tej scenicznej „bójki” bawi „automatyzmem” ludzkich zachowań. Już Henri Bergson dostrzegł komizm we wszystkim, co mechaniczne, odczłowieczające i zbliżone do martwego automatu. Por. idem, Śmiech. Esej o komizmie, przeł. S. Cichowicz, przedmowa S. Morawski, Kraków 1977, s. 43-234.

53 Są to informacje zawarte w didaskaliach; zob. Tragedia żebracza nowouczyniona ..., s. 253. 
Akcja dramatu kończy się rozejściem obydwu skonfliktowanych stron, które - złorzecząc sobie nawzajem - opuszczają gospodę. Zarówno Kupiec, jak i żebracy chcą bowiem uniknąć eskalacji konfliktu, który mógłby doprowadzić do rękoczynów i prawdziwego nieszczęścia. Jerzy Ziomek, komentując akcję tego przedstawienia, pisze: „Tragedia potrąca o tradycję dialogów i sporów na temat godności i wyższości stanów, przekonań, idei [...]. Mamy tu charakterystyczną odmianę śmiechu ambiwalentnego, gdzie śmiejący się jest wyśmiany i na odwrót. Jest to śmiech bez zwycięzcy" ${ }^{54}$. Można by go nazwać, według Ziomka, „karnawałowym”55. Trudno jednak się zgodzić z sugestią uczonego, jakoby tekst nie był satyrą. Ten śmiech, nazwany „karnawałowym”, jest satyryczny, ponieważ bezlitośnie obnaża mankamenty ludzkiej natury, na przykład skłonność do pychy i samochwalstwa, brak zrozumienia dla odmiennego stylu życia, nietolerancję, nieufność wobec „obcych” i w jakimś sensie ,innych” ludzi. Jak dowodzi bowiem jeden z badaczy karnawału: „Element satyryczny jest jednym z najbardziej stałych składników karnawału przed- oraz zaalpejskiego pomiędzy wiekiem XV a XIX [...]. Wygnać grzech i zło ze społeczeństwa, podobnie jak z rolnictwa i natury — łatwiej to powiedzieć, niż zrobić" ${ }^{56}$.

Warto zaznaczyć, że fabuła tego szesnastowiecznego tekstu jest realistycz$\mathrm{na}^{57}$, czyli wydarzenia i osoby występujące $\mathrm{w}$ dramacie są prawdopodobne, adekwatne do świata rzeczywistego, co różni ten utwór od drugiego analizowanego przez nas - Mięsopustu z roku 1622. Ma on akcję złożoną z sześciu aktów, zwanych „sprawami”, i wielu scen, w których przeważają pijackie ekscesy i zabawy mięsopustne, w tym przedstawienia z udziałem masek. Akcja tej siedemnastowiecznej komedii rozwija się w miarę przybywania nowych gości do karczmy, którzy zabawiają się śpiewem, tańcami, grą hazardową i raczą się napojami alkoholowymi (piwem, winem, gorzałką). Nawet imiona bohaterów dramatu śmieszą, ale też z góry charakteryzują postaci akcji. Plebejuszami są: Kostera — nałogowy hazardzista, Łapikufel - alkoholik, który nie chce dzielić się trunkami z kompanami, Marsjasz - wiejski grajek i inni. Przysiadający się do towarzystwa prostaków Sofista to zapewne jakiś student, bakałarz albo kościelny klecha, odznaczający się większą aniżeli pozostali uczestnicy zabawy, ogładą i wykształceniem. Maski zarówno Bachusa, jak i satyrów oraz sylenów są swoistym dziedzictwem europejskiego odrodzenia ${ }^{58}$, w Mięsopuście natomiast służą podkreśleniu tego, że

54 J. Ziomek, Renesans..., s. 121.

55 Ibidem.

56 E. Le Roy Ladurie, Święto zimowe: karnawat w Romans 1579-1580, przeł. Ł. Jurasz-Dudzik, [w:] Karnawat. Studia historyczno-antropologiczne, wyb., oprac. i wstęp W. Dudzik, Warszawa 2011, s. 188.

57 Pojęcie „realizm” rozumiem zgodnie ze współczesnym Stownikiem terminów literackich: M. Głowiński et al., Słownik terminów literackich, red. J. Sławiński, Wrocław 2000, s. 462.

58 O ,antykizacji” karnawału zob. W. Wojtowicz, op. cit., s. 288. Bodaj jako pierwszy maskaradę „ludowych sztuk bachicznych” dostrzegł S. Windakiewicz, który wprawdzie nie pisał, że w Mięsopuście operuje się maskami, ale dostrzegł komizm postaci wynikający z przebieranek (no- 
należy czynnie wykorzystywać karnawałowy czas na zabawę i delektowanie się mocnymi używkami.

Badacze karnawału uznają, że przez pojęcie maski należy rozumieć „całość wykorzystanych środków, czyli zasłonę twarzy, kostium i samego „aktora”; to dopiero tworzy kompletną „maskę w działaniu”59. Jest oczywiście pewne pokrewieństwo między siedemnastowieczną komedią karnawałową a na przykład włoską komedią dell'arte, co już wcześniej zauważyli uczeni ${ }^{60}$, ale w związku ze specyfiką staropolskiej kultury, tradycji i mentalności, zarówno szlacheckiej, jak i mieszczańskiej czy nawet chłopskiej (bo włościanie też przecież byli widzami sceny popularnej), nasze rodzime przedstawienia karnawałowe dostosowane były do gustów polskich odbiorców.

Przybranie obcego kostiumu, czyli maskarada, ma podkreślać czasowe zerwanie z codziennością, chęć oddzielenia się od życia zwykłego, przejście do świata fikcyjnego, w którym trwa mięsopustne święto ${ }^{61}$. Przykładem przedstawień maskaradowych jest przybycie do karczmy boga Bachusa - fictio perso$n a e^{62}-\mathrm{z}$ orszakiem satyrów i sylenów, którzy zachęcają obecnych w karczmie do zabawy i pijatyki. Maskaradą można też nazwać niezwykłą przemianę pijaka o „mówiącym” imieniu Łapikufel w wołu, którego w części finalnej dramatu gonią dwa diabły (czytaj: raczej maski diabłów), co ma oczywiście wymiar symboliczny, a jest konsekwencją nadużywania przez nieszczęśnika mocnych napojów. Śmieszy ponadto nieudana próba przywłaszczenia owego wołu-Łapikufla przez Karczmarza i jego syna, którzy chcą zabłąkane w swej zagrodzie zwierzę zaprząc do robót polowych lub zabić na mięso. Dawnych widzów musiała bawić sytuacja zaganiania wołu do chlewa. Śmieszyły też zapewne potyczki „przemienionego” w zwierzę Łapikufla z karczmarzami, którzy nie byli świadomi, że pod „bydlęcą” maską kryje się człowiek. Komizm ten, wynikający z pomyłki, ma swoje dydaktyczne przesłanie, utrwalone zresztą w literaturze i kulturze staropolskiej, a wynikające z porównania osobnika pijanego do bezrozumnego zwierzęcia ${ }^{63}$.

Komizm akcji osiąga się w tekście barokowym nie tylko poprzez działania i wypowiedzi masek, ale również, podobnie jak w Tragedii żebraczej, poprzez kontrast, czyli zestawianie $\mathrm{z}$ sobą dialogów osób pochodzących z różnych środo-

tabene badacz popełnił pomyłkę, pisząc, że Łapikufel jest przebrany „za satyra”, bo z didaskaliów wyraźnie wynika, że pijak jest ucharakteryzowany na wołu). Uczony dostrzegł jednak komizm postaci Łapikufla, wynikający z przebrania i działania; zob. idem, op. cit., s. 158-160.

59 Ȧ. Boholm, Weneckie widowiska karnawałowe, przeł. J. Jaworska, [w:] Karnawat. Studia historyczno-antropologiczne..., s. 207.

60 Por. B. Judkowiak, Komedia dell'arte i teatr jarmarczny w Europie, „Ruch Literacki” 1996, z. 3, s. 383-385; P. Pirecki, op. cit., s. 307.

61 E. Le Roy Ladurie, op. cit., s. 178.

62 O fictio personae zob. H. Lausberg, Retoryka literacka: podstawy wiedzy o literaturze, przeł., oprac. i wstęp A. Gorzkowski, Bydgoszcz 2002, s. 826-829.

63 Por. J. Kochanowski, O Koźle, [w:] idem, Dzieła polskie, oprac. J. Krzyżanowski, t. 1, Warszawa 1967, s. 173-174. 
wisk, co rodzi zabawne nieporozumienia. Już na początku dramatu rozmowa prostaków z Sofistą nieuchronnie prowadzi do efektów komicznych, co jest rzecz jasna związane z innym sposobem nie tylko mówienia, ale i myślenia oraz działania. Zresztą nawet Sofista nie jest bynajmniej konsekwentny w swym postępowaniu, bo najpierw zarzeka się, że nie będzie pił alkoholu, lecz z czasem ulega ogólnej atmosferze pijaństwa oraz rozpasania i sam domaga się dla siebie mocnych trunków.

Innym sposobem osiągania efektów komicznych są parodie, na przykład pseudouczony wykład Sofisty o etymologii i znaczeniu słowa aquavita (,woda życia”, a po polsku „gorzałka”). Komizm tej parodystycznej przemowy bierze się z celowego złamania decorum, czyli nieadekwatności błahego przedmiotu wypowiedzi do wzniosłego ujęcia treści. Śmieszyła bowiem w XVII wieku i śmieszy też dzisiaj rozbudowana i zmyślona etymologia tego słowa, nawiązywanie Sofisty do rozmaitych figur retorycznych i tropów. Nie jest to jedyna mowa parodystyczna w dramacie. Inną parodię — na przykład wzniosłej mowy panegirycznej Sofista prezentuje, witając przybywającego do karczmy bożka Bachusa: „Witaj! Przemożnych bogów zacne plemię / Witaj! Uciecho sauromackiej ziemie"64. Podniosłość apostrofy wymagałaby powagi i dostojnej atmosfery, czego trudno doszukiwać się w wiejskiej karczmie pełnej pijaków. Zatem i w tym przypadku bawi złamanie zasady stosowności. Poza tym nazywanie pogańskiego boga winnej latorośli, płodności, urodzaju, starożytnych zabaw przy tańcach i winie — „dawcą czasu wesołego” oraz „ochłodą narodu ludzkiego"65 ma wymiar symboliczny, bo odnosi się do okresu rozwiązłości karnawałowej, tolerowanej na ogół w XVI i XVII wieku przez hierarchów Kościoła katolickiego ${ }^{66}$. Po niej zawsze przychodzi codzienność, obwarowana licznymi rygorami, nakazami i ograniczeniami wynikającymi nie tylko z podporządkowania się nauce Kościoła, ale też z konieczności zaakceptowania przez ludzi nierówności społecznych i przedziałów stanowych. Nawiedzający karczmę Bachus podkreśla ograniczoność czasu świętowania i zabaw mięsopustnych: „Wielka czasu potęga, wielka jego władza. Czas nam wszystko przynosi, i z czasem odchodzi / [...] Dobrze zażywać, kiedy

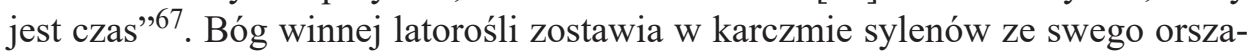
$\mathrm{ku}$, zachęca do radowania się, po czym rusza dalej w świat. Okres karnawałowy

64 Ibidem, s. 413-414.

65 Ibidem.

66 Jedna z interpretacji zjawiska, jaką zaproponował Dietz-Rüdiger Moser, wyjaśnia nawet, że karnawał był narzędziem katechetycznym w rękach Kościoła; chodziło bowiem w tym szczególnym okresie „mięsopustu” o uwolnienie wszelkich cielesnych i ziemskich żądz wiernych, aby po okresie wyuzdania nastąpił gorliwy powrót do właściwych chrześcijańskich wartości. „Wszystkie ekscesy, obżarstwo i dziwaczne przebrania miałyby służyć temu, aby ludzie dający się rzeczywiście na krótko ponieść grzesznym impulsom, w czasie postu mogli odwrócić się od ziemskiej ohydy i skupić na Królestwie Bożym" - P. Pfrunder, Gtówne koncepcje historycznych badań karnawatu, przeł. A. Brańka-Banasiak, W. Dudzik, [w:] Karnawat. Studia historyczno-antropologiczne..., s. 42.

67 Mięsopust abo tragicocomaedia..., s. 414-415. 
podlega więc powszechnemu prawu nieustannego ruchu, zmiany, metamorfozy dokonującej się w ludziach i w świecie.

Najbardziej wartko rozwija się akcja już po opuszczeniu karczmy przez Bachusa, gdyż wraz z narastającą atmosferą rozluźnienia, wynikającą nie tylko z pijaństwa, lecz także hazardu - czyli gry w kości i karty, następuje intensyfikacja działań bohaterów. Wpływ mocnych trunków i hazardowych emocji na gości karczmy przejawia się zachowaniem chaotycznym, spontanicznym i irracjonalnym, o czym informują didaskalia: zarówno główne postaci dramatu (Łapikufel, Kostyra, Sofista, Marsjasz), jak i osoby z orszaku Bachusa tańczą ${ }^{68}$ śpiewają wesoło (ale każdy nuci na scenie inną, własną piosenkę, więc słowa i melodie mieszają się z sobą). Ponadto didaskalia zachęcają aktorów do inwencji, na przykład skoków, strojenia min, wygibasów (por. informacja w didaskaliach: „Na ostatek, co kto będzie umiał, wyprawi" ${ }^{\prime 99}$ ). Ten zamierzony chaos, nieskoordynowane ruchy pojedynczych osób, brak logicznej wymiany myśli i współdziałania ludzi z sobą przywodzi na myśl zepsuty mechanizm, co oczywiście śmieszy ${ }^{70}$, ale z takiego widowiska wynika też jakiś groteskowy niepokój. Podtekst przedstawienia ma bowiem wymiar satyryczno-dydaktyczny, sugerujący zarówno widzom, jak i samym aktorom, że śmieją się z samych siebie, z własnych słabości, grzechów i ludzkich ułomności.

Po wyjściu z karczmy Bachusa w dramacie pojawiają się wątki poboczne, na przykład wątek Karczmarza i jego syna. Smutny epizod płaczącego z powodu śmierci żony Karczmarza zostaje przełamany pocieszeniami prostaka Łapikufla, który radzi właścicielowi karczmy ponowny ożenek. Motyw śmierci pojawia się wszakże często zarówno w karnawale, jak i w widowiskach mięsopustnych, ale bywa neutralizowany właśnie poprzez śmiech. W analizowanym przedstawieniu komiczne jest na przykład rajenie żałobnikowi nowej żony przez jednego z satyrów. Wszystkie „kandydatki” na małżonki są rzekomo „urodziwe”" czywistości uroda ta pozostaje $\mathrm{w}$ sprzeczności z tradycyjnym pojmowaniem doskonałości i harmonii kształtów:

I wszytkie urodziwe, wszytkie okazałe.

Jedna chodzi jak fasa, co nasubtelniejsza,

Chroma, i z krzywą gębą. A co najpiękniejsza,

Zawsze jej z nosa kapie, gęba jak kaleta,

Ktemu o jednym oku ${ }^{72}$.

68 O tańcu jako „metaforze aktu seksualnego” i symbolicznym wyrazie rozpasanej seksualności w tekstach ,zapustnych” pisze W. Wojtowicz, op. cit., s. 298-300 n.

69 Mięsopust abo tragicocomaedia..., s. 423.

70 Jak zauważył Bergson: „Postawa, gesty i ruchy ludzkiego ciała są śmieszne dokładnie w tej mierze, w jakiej ciało to przywodzi na myśl bezduszny mechanizm" - idem, op. cit., s. $72 \mathrm{n}$.

71 Mięsopust abo tragicocomaedia..., s. 427.

72 Ibidem. 
Oczywiście w tym wypadku śmieszy celowa deformacja, karykaturalne odstępstwo od uznanego kanonu kobiecego piękna.

Satyryczne zacięcie omawianego widowiska karnawałowego związane jest nie tylko z pokazywaniem zgubnych skutków nadużywania napojów alkoholowych, co pozbawia pijaków człowieczej godności. W parodystyczny sposób przedstawiona została na przykład siedemnastowieczna szkoła parafialna, o której opowiadają prostacy (Łapikufel, Kostyra):

Bo w jednym warcabnice kącie rozkładają,
W drugim zaś czterech królów księgi więc czytają.
W trzecim w arytmetykę wprawują się pilnie [...]
Najdziesz też niepoślednich tam matematyków,
Najdziesz i astrologów, i przednich muzyków [...]
My kiedykolwiek chmielem głowę obłożymy,
Wznak leżąc i pod dachem, gwiazdy więc liczymy ${ }^{73}$.

Daremne wydają się bowiem wysiłki nauczycieli pragnących zaszczepić umiłowanie mądrości tępym uczniom, predestynowanym nie do naukowych zajęć, ale do pracy na roli, a symbolem tej ostatniej jest narzędzie rolnicze - socha: „Bawej! To ty nas czynić chcesz astrologami, / Snadź owemi, co dzwonią o sochę nogami" ${ }^{\prime \prime}$.

W momencie kiedy Sofista drwi z prostaka Łapikufla, nazywając go ,geometrą", a więc przydomkiem zupełnie niepasującym do wieśniaka, prowokuje znów śmiech widowni, wynikający z nieodpowiedniości określenia do osoby. Nie jest to pierwszy przykład zjadliwej ironii rybałtowskiego pisarza wobec przedstawiciela chłopstwa ${ }^{75}$. Pochwałę ironii jako środka wywoływania komizmu przez ludzi kulturalnych i wykształconych wyraził już Arystoteles w Retoryce ${ }^{76}$ (1419b). Widać więc, że rybałtowscy pisarze znali i stosowali w swych dziełach ten środek ekspresji. Technikę wywoływania odczuć komicznych poprzez zabawną grę słów, na zasadzie luźnych skojarzeń, stosuje także Kostera. Mówi on mianowicie o swej aparaturze „naukowej” i niejako zderza z sobą nazwy przyrządów astrologicznych, na przykład astrolabium, z akcesoriami pijaka: beczką alkoholu, konwią, którą mierzy się gorzałkę: „Miasto astrolabium, beczką się bawimy, / a zaś, miasto quadransa, konwią ją mierzymy" ${ }^{\text {"7 }}$. Komizm słowny powstaje ponadto

73 Ibidem, s. 407, 410.

74 Ibidem, s. 409.

75 Przykładem eksponowania dumy rybałtowskiego pisarza, który wyraźnie podkreśla swą wyższość stanową nad chłopstwem, jest przypisywany Janowi z Kijan wiersz Psalm na ogorzelinę: „Rybałt na zimę biały, a na lato rumiany, / Jako kwiat różany. / A chłop na zimę czarny, a na lato rudawy, / Jako pies sadawy [...] U rybałtowskiej łożnice wiszą lutnie i skrzypice, / co nimi cieszy dziewice. / A u chłopowej łożnice wiszą cepy i kłonice [...]" — Polska fraszka mieszczańska. Minucje sowiźrzalskie, oprac. K. Badecki, Kraków 1948, s. 152-153. Niechęć do chłopów i przedrzeźnianie ich gwary da się zauważyć także w sowizdrzalskich anegdotach i powiastkach pisanych prozą.

76 Zob. Arystoteles, Retoryka..., s. 477.

77 Mięsopust abo tragicocomaedia..., s. 410. 
przez przeinaczanie przez wieśniaków nazw figur retorycznych. O figurach tych mówi popisujący się swą uczonością Sofista, ale pozostali bywalcy karczmy nie rozumieją jego wypowiedzi. Mianowicie na przykład Łapikufel nazwę „metonimia” zamienia na „matanina”, a metalepsis w jego wydaniu to „miotalepsza” ${ }^{\prime 78}$, co w prosty sposób kojarzy się z określeniem „miotła lepsza”.

Autor książki o polskiej komedii sowizdrzalskiej zwrócił uwagę na funkcje postaci diabłów w Mięsopuście:

Jako reprezentanci zła i symbole piekła usidlają człowieka, jednocześnie przyjmując ludzkie cechy i zasady postępowania. Tak ukształtowani są pozbawieni demonicznej mocy, doskakują do Łapikufla z obu stron, jakby zachęcali do zabawy, a nie sporu — komicznej gry o duszę ${ }^{79}$.

Śmieszne są więc zarówno maski kosmatych diabłów, jak i osoba pijaka przebranego w zwierzę pociągowe, bawi też sytuacja pląsów człowieka z przedstawicielami piekieł, zakończona ucieczką pijanicy przed demonami. Jak bowiem zauważył badacz, z potęgi czartowskiej „ludowa komedia wyraźnie kpi" ${ }^{80}$. Demoniczne zło zostało więc, dopowiedzmy, zneutralizowane - nie zagraża już człowiekowi, a szatan przeistoczył się, jakby powiedział Michaił Bachtin, w „wesołe śmieszne straszydło" 81 .

Warto dodać, że, jak wynika z wcześniejszej rozmowy gości karczmy, przemiana Łapikufla w zwierzę pociągowe jest pozorna, bo to towarzysze zabaw przebrali najgorszego spośród siebie pijanicę za wołu, doklejając mu rogi i sztuczną sierść. Wykorzystując zamroczenie alkoholowe swego kompana, jego oszołomienie i głupotę, postanowili się jego kosztem zabawić, a tym samym zrobić mu na złość, dać nauczkę za jego egoizm (nie chciał się bowiem dzielić z innymi piwem i winem). Świadomość umowności i symboliki masek w siedemnastowiecznej komedii karnawałowej, wystawianej na scenie ludowej, musiała być zatem podzielana zarówno przez aktorów, jak i widzów. Ci ostatni, oglądając przedstawienie, przeżywali w ten sposób okres ponoworocznych zabaw, dając się ponieść atmosferze maskarady jak trafnie charakteryzuje kulturoznawca — ,przepełnionej duchem dionizyjskim, pełnej usmolonych twarzy, tańców, wywijania miotłami [...]. Prowadzi to do świata bogatych królestw, do Kokanii, krainy mlekiem i miodem płynącej [...] tędy wiedzie droga do »świata na opak« i w dziedzinę cudów (odwrócenie)»82.

Motyw Kokanii pojawia się także w omawianym siedemnastowiecznym dramacie (tu idealna kraina nazywa się „Utopija”). Ten świat niezwykłego dostatku wyłania się z opowieści przybyłego do karczmy Pielgrzyma. Wędrowiec zmyśla

78 Ibidem, s. 406.

79 P. Pirecki, op. cit., s. 100.

80 Ibidem, s. 101.

81 M. Bachtin, Wstęp (sformułowanie problemu), [w:] idem, Twórczość Franciszka Rabelais 'go a kultura ludowa średniowiecza i renesansu, przeł. A. i A. Goreniowie, oprac., wstęp i kom., weryfikacja przekładu s. Balbus, Kraków 1975, s. 66, 112 n.

82 E. Le Roy Ladurie, op. cit., s. 179. 
dziwy, w które prostacy (Łapikufel i Kostera) są skłonni uwierzyć, ale reagujący na tę opowieść ironicznym gwizdem Sofista nie jest już tak łatwowierny. Komizm wypowiedzi Pielgrzyma wynika bowiem z absurdalnych zmyśleń o cudownej krainie, w której można zobaczyć drabiny z piór ptasich, drzewa z żelaza i metali szlachetnych, a w gajach żyją mrówki większe od słoni. Natomiast ludzie w owej krainie latają w powietrzu, choć nie mają skrzydeł. Ten opierający się na absurdzie humor jest typowy dla literatury sowizdrzalskiej (szczególnie widoczny w krótkich prozatorskich nowinach, których autorzy podpisywali się pseudonimami: Józef Pięknorzycki i Cadasylan Nowohracki ${ }^{83}$ ) i dla anegdot z kręgu staropolskiego stowarzyszenia humorystycznego, zwanego Rzecząpospolitą Babińską ${ }^{84}$.

Dlaczego odbiorcy ówczesnego dramatu sowizdrzalskiego lubowali się w humorze wynikającym z absurdu? Zapewne dlatego, że ich przywiązanie do realiów życia codziennego było mocne, a kontakt $\mathrm{z}$ innymi kulturami o odmiennych obyczajach i stylu życia - słaby, gdyż na podróże w dalekie kraje mogli sobie pozwolić tylko najzamożniejsi; poza tym tworzyły się ówcześnie dopiero zalążki prasy, a innych mediów nie znano ${ }^{85}$. I chociaż z wielką ciekawością wysłuchiwano opowieści wędrownych kupców, rybałtów czy żebraków o obcych krajach, to nic dziwnego, że wszelkie odstępstwa od normy, a więc zwykłego życia, budziły niedowierzanie i śmiech. Wypowiedź Pielgrzyma wydaje się parodią owych nowin o dziwach, które pojawiały się w XVII stuleciu zarówno w formie ustnej, jak i w postaci drobnych druczków nowiniarskich, powielanych przez drukarnie, zwłaszcza krakowskie, dla zarobku, a chętnie kupowanych przez mieszczan i szlachtę na jarmarkach czy odpustach.

Omawiany siedemnastowieczny dramat, podobnie jak widowisko Tragedii żebraczej, kończy się dobrze, bo nikt nie zostaje skrzywdzony, a „przemieniony" w zwierzę Łapikufel nie będzie porwany do piekła przez kulawych diabłów. Wprawdzie uciekając do swego domu, boi się reakcji rozzłoszczonej na niego żony, ale — jak głosi Epilog — demony go nie dogonią.

${ }^{83}$ Zob. Nowiny polskich sowiźrzałów, [w:] Polska satyra mieszczańska, oprac. K. Badecki, Kraków 1950, s. 269-343.

${ }^{84}$ Por. Akta Rzeczypospolitej Babińskiej wedtug oryginalnego rękopisu, oprac. S. Windakiewicz, „Archiwum do Dziejów Literatury i Oświaty w Polsce”, t. 8, Kraków 1895, s. 33-159. O Rzeczypospolitej Babińskiej pojawiło się ostatnio sporo opracowań; zob. m.in. A. Kuś, Rzeczypospolita Babińska - parodia i utopia, „Odrodzenie i Reformacja w Polsce” 47, 2003, s. 140 n.; T. Banaś, Pomiędzy tragicznościa a groteska. Studium z literatury i kultury polskiej schytku renesansu i wstępnej fazy baroku, Katowice 2007, s. 137-168; D. Künstler-Langner, ,Homo ridens” w Rzeczypospolitej Babińskiej i w królestwie Sowizdrzała. O śmiechu w literaturze staropolskiej, [w:] Polonistyczne drogi. Księga jubileuszowa poświęcona profesorowi Władysławowi Sawryckiemu, red. M. Wróblewski, Toruń 2008, s. 53-59; W. Wojtowicz, „Literatura sowizdrzalska” a ,Rzeczpospolita Babińska”, [w:] idem, Między literatura a kulturą..., s. 278-283.

85 Zob. K. Zawadzki, Gazety ulotne polskie i Polski dotyczace XVI-XVII wieku: bibliografia, t. 1-3, Wrocław 1977-1990; idem, Początki prasy polskiej. Gazety ulotne i seryjne XVI-XVIII wieku, Warszawa 2002. 
Dotychczasowy stan badań nad staropolskim dramatem mięsopustnym wskazuje na mnożenie gatunkowych nazw, za czym nie podąża pogłębiona analiza genologiczna tych tekstów. Skupiając się na praktyce twórczej i uwzględniając stan badań nad staropolską poetyką sformułowaną, przyporządkowałam konkretnym dokonaniom twórczym nazwę „tragikomedia mięsopustna”, co jest zgodne z terminologią zapisaną $\mathrm{w}$ dawnych kompendiach poetyki. Aby prześledzić typy komizmu i kierunek ewolucji gatunku, skupiłam się na dwu reprezentatywnych dla tragikomedii utworach, pochodzących z renesansu i baroku. Porównując zarówno akcję, jak i typ bohaterów i sposób konstruowania żartu słownego przez anonimowych autorów dwu widowisk staropolskich — z XVI oraz XVII stulecia — określanych przez badaczy jako dramaty ,mięsopustne”, można się w nich dopatrzyć pewnych podobieństw, ale i różnic. W dramacie siedemnastowiecznym sytuacji komicznych jest znacznie więcej niż w Tragedii żebraczej, w której akcja opiera się na jednym tylko wątku (konflikt żebraków z kupcem). W obu widowiskach sceny wesołe przeplatają się ze smutnymi, lecz finał całości jest pomyślny. Komizm bywa osiągany głównie przez kontrast i niespodziankę (kontrastowe zestawianie z sobą postaci o różnej mentalności, sposobach myślenia i mówienia; kontrast między stereotypowymi wyobrażeniami a autentycznym wizerunkiem osób, nieadekwatność deklaracji w stosunku do rzeczywistych czynów, co widać na przykład w działaniu Sofisty, łamanie zasady decorum, niespodziewane zachowania niektórych scenicznych postaci, chociażby skoczny taniec rzekomo chorego i kulawego żebraka, który okazuje się zdrów jak ryba). W obu dramatach obserwujemy humor, który mieści się w staropolskiej koncepcji „komizmu satyrycznego, zasadzającej się na świadomej i celowej degradacji przedmiotu poprzez uwydatnienie i ośmieszenie jego cech negatywnych" ${ }^{\circ 6}$. Ważnym więc sposobem wywoływania śmiechu jest degradacja, ale taka, o której pisał Arystoteles: nieszkodliwa i „bezbolesna"87 (V, 1449a, 35), czyli niepowodująca nieszczęścia bohaterów i niebudząca u odbiorców litości i trwogi (na przykład zdegradowany w swym człowieczeństwie Łapikufel przemieniony w wołu czy poniżony przez żebraków pyszałkowaty Kupiec). Postaci sceniczne w obydwu tekstach mają specyficzne imiona, które kojarzą się z konkretną cechą wyglądu lub charakteru danej jednostki, jakąś wadą czy upodobaniem. Zgodnie z wywodzącą się z prastarej tradycji grecko-rzymskiej poetyką sformułowaną komedii ${ }^{88}$ osoby dramatu najbardziej budzące śmiech pochodzą ze stanu niskiego: są to głównie chłopi, żebracy. Sposób ich mówienia jest potoczny, wzorowany na języku codziennym ludzi ze społecznych nizin. Ich zachowanie zaś — tak jak zalecały dawne poetyki

86 T. Michałowska, Komizm..., s. 334.

87 Arystoteles, Poetyka..., s. 15.

88 T. Michałowska, Poezja dramatyczna (dramatica poesis), [w:] eadem, Staropolska teoria genologiczna..., s. 100-106, 163-164. 
sformułowane - wzorowane było na codziennym życiu prostaków. W Tragedii żebraczej i w siedemnastowiecznym Mięsopuście ośmieszani są też bohaterowie dostojni: nobliwy kupiec oraz uczony (Sofista). Można to prawdopodobnie wiązać ze swoistością widowisk mięsopustnych, albowiem czas karnawału powoduje wypowiedzi oraz działania „na opak” ludzi wielu środowisk społecznych. Poza tym poetyka sformułowana XVII wieku dopuszczała obecność w tragikomedii osób wyższych stanów. Julian Lewański pisał przed laty:

Komizm utworów sowizdrzalskich łączył się przede wszystkim z zarysowaną dla całej akcji ramą sytuacyjną, z której następnie wynikały kolejno realizowane spięcia, rozśmieszające widownię. Był to więc dramat [...], w którym [...] elementy komiczne bywały mechanicznie dołączane (w postaci żartów językowych, facecji, starć fizycznych, żonglerki) ${ }^{89}$.

Trzeba dodać, że żartów słownych, wynikających na przykład z przekręcania sensu słów, wieloznaczności, udziwnionych neologizmów, jest znacznie więcej w siedemnastowiecznym Mięsopuście niż w utworze renesansowym. Podkreślmy, że w większości widowisk sowizdrzalskich komizm nie wiąże się wyłącznie z funkcją ludyczną (zabawową), ale odgrywa rolę służebną w stosunku do funkcji dydaktycznej. Wnioskować więc można, że na wykształcenie się literackiej i scenicznej formy tragikomedii mięsopustnej znaczny wpływ wywarły średniowieczne moralitety.

Analiza wskazanych dramatów dowodzi, że elementy komiczne nie tylko są dołączane do samej akcji, lecz także wynikają z jej przebiegu: irracjonalne i śmieszne zachowania żebraków w Tragedii żebraczej lub bohaterów Miesopustu są konsekwencją ich wcześniejszych działań i wypowiedzi. Obydwa rozpatrywane przeze mnie utwory mają, już w prologu, jasno zaznaczoną sytuację, z którą bezpośrednio wiążą się następujące po sobie zabawne epizody, przerywane scenami smutnymi lub lamentacyjnymi wypowiedziami bohaterów, znajdujących się w trudnym położeniu (na przykład skarżący się, posiniaczony i pobity Kupiec — bohater dramatu szesnastowiecznego - czy też płaczący po swej zmarłej małżonce Karczmarz z widowiska siedemnastowiecznego).

Bardziej rozpoznawalny jako dramat mięsopustny jest utwór barokowy, zawierający sporo aluzji do czasu karnawałowego i zabawy ponoworocznej ${ }^{90}$. Tekst z XVII stulecia sygnalizuje także więcej zróżnicowanych środków scenicznych, mających budować sytuacje komiczne, na przykład informacja w didaskaliach odnosząca się do mimiki czy — bliskich pantomimie — błazeńskich ruchów aktorów, co wiąże się także z wyglądem, działaniem i charakterystycznymi cechami postaci-masek. Maskarada słabo jest jeszcze zarysowana w tragikomedii renesansowej (poprzez zrzucenie łachmanów przez żebraków). W obydwu utworach

89 J. Lewański, Komedia..., s. 327.

90 Można go nazwać tekstem „skarnalizowanym”; por. A. Skubaczewska-Pniewska, Teoria karnawalizacji Michała Bachtina, [w:] Teoria karnawalizacji. Konteksty i interpretacje, red. A. Stoff, A. Skubaczewska-Pniewska, Torun 2011, s. 54-55 n.; V. Wróblewska, Różne oblicza karnawalizacji, [w:] Teoria karnawalizacji. Konteksty i interpretacje..., s. 37-38 n. 
istnieje typ humoru oparty na absurdzie, ale tylko autor widowiska barokowego zastosował parodię, a także ironię, która ujawnia się chociażby w postawie i wypowiedziach Sofisty reagującego na kłamstwa Pielgrzyma o cudownej krainie. O tym subtelniejszym środku wywoływania komizmu pisał już Arystoteles: „Kulturalnemu człowiekowi bardziej przystoi ironia niż błazeństwo. Ironizujący żartuje bowiem dla własnej przyjemności, błazen dla cudzej"91 (1419b).

W widowisku barokowym zauważalna jest również dążność do urozmaicania akcji, zwiększania liczby typów bohaterów komediowych oraz żartów słownych, wykorzystujących grę słowną, zabawne skojarzenia, podobieństwo brzmieniowe i ambiwalencję znaczeń. Dramatom mięsopustnym, eksponującym w sposób dosadny funkcję ludyczną, mimo wszystko przyświeca dydaktyzm, co współgra z preferowanym typem komizmu, nazwanym przez Łukasza Górnickiego „trefnością z uszczknieniem”.

Zestawienie z sobą dwu tragikomedii mięsopustnych, powstałych w dobie renesansu i baroku, pozwala dostrzec ewolucję tego gatunku, polegającą nie tylko na rozbudowywaniu wątków dramatycznych, lecz także na wzbogaceniu i urozmaiceniu środków powodujących zaistnienie komizmu.

\section{Bibliografia}

\section{Literatura podmiotu}

Akta Rzeczypospolitej Babińskiej wedtug oryginalnego rękopisu, oprac. S. Windakiewicz, „Archiwum do Dziejów Literatury i Oświaty w Polsce”, t. 8, nakładem Akademii Umiejętności, Kraków 1895.

Arystoteles, Poetyka, przeł. i oprac. H. Podbielski, Wydawnictwo Zakładu Narodowego im. Ossolińskich, Wrocław 1983.

Arystoteles, Retoryka, przeł., wstęp i kom. H. Podbielski, [w:] idem, Dzieła wszystkie, t. 6. Polityka, Ekonomika, Retoryka, Retoryka dla Aleksandra, Poetyka, Zachęta do Filozofii, Ustrój polityczny Aten, list do Aleksandra Wielkiego, Testament, Państwowe Wydawnictwo Naukowe, Warszawa 2001.

Dramaty staropolskie. Antologia, oprac. J. Lewański, przyp. M. Bokszczanin, t. 1, Państwowy Instytut Wydawniczy, Warszawa 1959.

Górnicki Ł., Dworzanin polski, t. 2, oprac. R. Pollak, Wydawnictwo Zakładu Narodowego im. Ossolińskich, Wrocław 2004.

Kochanowski J., Dzieła polskie, oprac. J. Krzyżanowski, t. 1, Państwowy Instytut Wydawniczy, Warszawa 1967.

Polska fraszka mieszczańska. Minucje sowiźrzalskie, oprac. K. Badecki, nakładem Polskiej Akademii Umiejętności, Kraków 1948.

Polska komedia rybattowska, oprac. K. Badecki, Wydawnictwo Zakładu Narodowego im. Ossolińskich, Lwów 1931.

Polska satyra mieszczańska. Nowiny sowiźrzalskie, oprac. K. Badecki, nakładem Polskiej Akademii Umiejętności, Kraków 1950.

91 Arystoteles, Retoryka..., s. 477. 


\section{Literatura przedmiotu}

Bachtin M., Twórczość Franciszka Rabelais'go a kultura ludowa średniowiecza i renesansu, przeł. A. i A. Goreniowie, oprac., wstęp i kom., weryfikacja przekładu S. Balbus, Wydawnictwo Literackie, Kraków 1975.

Banaś T., Pomiędzy tragicznością a groteską. Studium z literatury i kultury polskiej schyłku renesansu $i$ wstepnej fazy baroku, Wydawnictwo Uniwersytetu Śląskiego, Katowice 2007.

Bergson H., Śmiech. Esej o komizmie, przeł. S. Cichowicz, przedmowa S. Morawski, Wydawnictwo Literackie, Kraków 1977.

Bibliografia Literatury Polskiej „,Nowy Korbut”, t. 2. Piśmiennictwo staropolskie, oprac. zespół red. pod kierunkiem R. Pollaka, Państwowy Instytut Wydawniczy, Warszawa 1963.

Bieńkowski T., Gatunki dramatyczne w okresie staropolskim (wstępne klasyfikacje), „Ruch Literacki” 11, 1970, z. 2, s. 93-98.

Budzyk K., Komedia sowizdrzalska, „Pamiętnik Literacki” 43, 1952, z. 3-4, s. 814-866.

Budzyk K., Studia z zakresu nauk pomocniczych i historii literatury polskiej, t. 2, Zakład im. Ossolińskich-Wydawnictwo Polskiej Akademii Nauk, Wrocław 1956.

Bystroń J.S., Dzieje obyczajów w dawnej Polsce. Wiek XVI-XVIII, t. 2, Państwowy Instytut Wydawniczy, Warszawa 1976.

Chemperek D., ,Z chłopa król” Piotra Baryki - historia, Shakespeare i tradycja literacka, „Pamiętnik Literacki" 52, 2003, z. 1-2, s. 5-35.

Dobrzycki S., Z dziejów literatury polskiej, Polska Spółka Wydawnicza, Kraków 1907.

Głowiński M., Gatunek literacki i problemy poetyki historycznej, [w:] Genologia polska. Wybór tekstów, wyb. i oprac. E. Miodońska-Brookes, A. Kulawik, M. Tatara, Państwowe Wydawnictwo Naukowe, Warszawa 1983.

Głowiński M., Kostkiewiczowa T., Okopień-Sławińska A., Sławiński J., Słownik terminów literackich, red. J. Sławiński, Zakładu Narodowy im. Ossolińskich, Wrocław 2000.

Grzeszczuk S., Błazeńskie zwierciadło. Rzecz o humorystyce sowizdrzalskiej XVI i XVII wieku, Universitas, Kraków 1994.

Hahn W., Literatura dramatyczna w Polsce XVI w., Nakładem Towarzystwa dla Popierania Nauki Polskiej, Lwów 1906.

Hernas C., Barok, Państwowe Wydawnictwo Naukowe, Warszawa 1976.

Judkowiak B., Komedia dell'arte i teatr jarmarczny w Europie, „Ruch Literacki” 1996, z. 3, s. 383 385 .

Kadulska I., Komedia w polskim teatrze jezuickim XVIII w., Wrocław 199.

Karnawat. Studia historyczno-antropologiczne, wyb., oprac. i wstęp W. Dudzik, Wydawnictwa Uniwersytetu Warszawskiego, Warszawa 2011.

Kleiner J., Studia z zakresu teorii literatury, Towarzystwo Naukowe Katolickiego Uniwersytetu Lubelskiego, Lublin 1961.

Künstler-Langner D., „Homo ridens” w Rzeczypospolitej Babińskiej i w królestwie Sowizdrzała. O śmiechu w literaturze staropolskiej, [w:] Polonistyczne drogi. Księga jubileuszowa poświęcona profesorowi Władysławowi Sawryckiemu, red. M. Wróblewski, Wydawnictwo Naukowe Uniwersytetu Mikołaja Kopernika, Toruń 2008, s. 52-59.

Kuś A., Rzeczypospolita Babińska - parodia i utopia, „Odrodzenie i Reformacja w Polsce” 47, 2003, s. 129-141.

Lausberg H., Retoryka literacka: podstawy wiedzy o literaturze, przeł., oprac. i wstęp A. Gorzkowski, Wydawnictwo Homini, Bydgoszcz 2002.

Le Roy Ladurie E., Święto zimowe: karnawat w Romans 1579-1580, przeł. Ł. Jurasz-Dudzik, [w:] Karnawat. Studia historyczno-antropologiczne, wyb., oprac. i wstęp W. Dudzik, Wydawnictwa Uniwersytetu Warszawskiego, Warszawa 2011.

Literatura i Kultura Popularna 26, 2020

(C) for this edition by CNS 
Lewański J., Dramat i teatr średniowiecza i renesansu w Polsce, Państwowe Wydawnictwo Naukowe, Warszawa 1981.

Lewański J., Studia nad dramatem polskiego odrodzenia, Zakład Narodowy im. Ossolińskich, Wydawnictwo Polskiej Akademii Nauk, Wrocław 1956.

Lewański J., Wstęp, [w:] Dramaty staropolskie. Antologia, oprac. J. Lewański, przyp. M. Bokszczanin, Państwowy Instytut Wydawniczy, Warszawa 1959.

Michałowska T., Staropolska teoria genologiczna, Zakład Narodowy im. Ossolińskich, Wrocław 1974.

Mieszek M., Intermedium polskie XVI-XVIII w. (teatry szkolne), Collegium Colombinum, Kraków 2007.

Okoń J., Dramat i teatr szkolny: sceny jezuickie XVII w., Zakład Narodowy im. Ossolińskich, Wroclaw 1970.

Pirecki P., Polska komedia plebejska XVI i XVII w. Zarys monograficzny, Wydawnictwo Uniwersytetu Łódzkiego, Łódź 2008.

Poetica practica anno domini 1648, [za:] V.I. Riezanov, K isstorii russkoj dramy. Ekskurs w oblast' tieatra jezuitov, Niežyn 1910, s. 302-373.

Pontanus J., Poeticarum Institutionum libri III, Ingolstadii 1597, starodruk Biblioteki Jagiellońskiej, sygn. BJ 59045 6/I.

Skubaczewska-Pniewska A., Teoria karnawalizacji Michała Bachtina, [w:] Teoria karnawalizacji. Konteksty i interpretacje, red. A. Stoff, A. Skubaczewska-Pniewska, Wydawnictwo Naukowe Uniwersytetu Mikołaja Kopernika, Toruń 2011.

Skwarczyńska S., Wstęp do nauki o literaturze, t. 3, Pax, Warszawa 1965.

Stownik literatury staropolskiej. Średniowiecze - renesans - barok, red. T. Michałowska przy udziale B. Otwinowskiej, E. Sarnowskiej-Temeriusz, Zakład Narodowy im. Ossolińskich, Wrocław 1990.

Teoria karnawalizacji. Konteksty i interpretacje, red. A. Stoff, A. Skubaczewska-Pniewska, Wydawnictwo Naukowe Uniwersytetu Mikołaja Kopernika, Toruń 2011.

Trzynadlowski J., Komizm, „Prace Polonistyczne” 1952, seria 10, s. 379-392.

Wallis M., Przeżycie i wartość. Pisma z estetyki i nauki o sztuce (1931-1949), Wydawnictwo Literackie, Kraków 1968.

Windakiewicz S., Teatr ludowy w dawnej Polsce, Akademia Umiejętności, Kraków 1902.

Wojtkowska-Maksymik M., , Gentiluomo cortigiano” $i$,dworzanin polski”. Dyskusja o doskonatości człowieka w ,Il Libro del Cortigiano” Baldassarra Castiglioniego i w „Dworzaninie polskim” Łukasza Górnickiego, Wydawnictwo Instytutu Badań Literackich Polskiej Akademii Nauk, Warszawa 2007.

Wojtowicz W., ,,Literatura sowizdrzalska” a „Rzeczpospolita Babińska”, [w:] idem, Między literaturq a kultura. Studia o ,literaturze mieszczańskiej” przełomu XVI i XVII wieku, Wydawnictwo Naukowe Uniwersytetu Szczecińskiego, Szczecin 2010, s. 278-283.

Wróblewska V., Różne oblicza karnawalizacji, [w:] Teoria karnawalizacji. Konteksty i interpretacje, red. A. Stoff, A. Skubaczewska-Pniewska, Wydawnictwo Naukowe Uniwersytetu Mikołaja Kopernika, Torun 2011.

Zawadzki B., Przegląd krytyczny ważiejszych teoryj komizmu, „Przegląd Filozoficzny” 1929, z. 1-2, s. 16-57.

Zawadzki K., Gazety ulotne polskie i polski dotyczqce XVI-XVIII wieku: bibliografia, t. 1-3, Zakład Narodowy im. Ossolińskich, Wrocław 1977-1990.

Zawadzki K., Początki prasy polskiej. Gazety ulotne i seryjne XVI-XVIII wieku, Biblioteka Narodowa, Warszawa 2002.

Ziomek J., Powinowactwa literatury. Studia i szkice, Państwowe Wydawnictwo Naukowe, Warszawa 1980.

Ziomek J., Renesans, Państwowe Wydawnictwo Naukowe, Warszawa 1995.

Literatura i Kultura Popularna 26, 2020

(C) for this edition by CNS 


\title{
On comedy in two Old-Polish dramas of the popular scene: Tragedia żebracza nowouczyniona (1552) and Mięsopust abo Tragicocomaedia (1622)
}

\author{
Summary
}

The aim of the article is to compare two old-Polish dramas of the so-called "popular scene", and thus point to the directions of evolution of carnival representations in the former Polish Nobles' Republic. The first work comes from the mid-sixteenth century and is characterised by a simple story. The second, written in the first half of the seventeenth century, has a vast plot and much more extensive stage directions. By contrasting both the story and the type of heroes and the way of constructing a verbal joke by anonymous authors, the author comes to the conclusion that although both performances meet the convention of old-Polish "tragicomedy", one can see not only similarities, but also significant differences. In Tragedia żebracza of 1552, the story is based on one plot only (the conflict between beggars and a merchant), while in the text written in the seventeenth century there are many more plots. In both texts, cheerful scenes are intertwined with sad ones (according to the then convention of "tragicomedy"), and the finales of the stories in both works are happy.

The comedy is achieved, both in the sixteenth- and seventeenth- century drama, mainly through contrast and surprise (e.g. contrasting characters with a different mentality, ways of thinking and speaking; the contrast between stereotypical images and authentic images of people, inadequacy of declarations in relation to real people, behaviour of some stage characters incompatible with the viewer's expectations, an example of which is a lively dance of an allegedly sick and lame beggar, etc.) In both texts we observe a type of humour that fits into the old-Polish concept of so-called "satirical comedy". This means that some characters are consciously and deliberately degraded by ridiculing and highlighting their negative traits. Thus, comic elements do not serve only a ludic function and are not merely "attached" to the story itself to achieve humorous effects, as Julian Lewański, a researcher of old-Polish drama, wrote many years ago. This is because comedy also serves for didactic purposes.

More recognizable as a "carnival" drama is the seventeenth-century work. It contains, unlike the sixteenth-century work, a lot of allusions to the carnival time and post-New Year's party (organised after t New Year's Day). In the extended stage directions of the Baroque text, the author signalled much more stage means to build comic situations than in the sixteenth-century drama, for example, the author's information on the facial expressions or, close to pantomime, the actors' clownish movements are significant. This is related to the appearance, the action and the characteristics of the mask-characters. The masquerade is still very poorly outlined in Renaissance tragicomedy (removing rags and putting on beautiful robes by the beggars can be treated as the masquerade). The Baroque text is dominated by stage characters wearing masks. In the seventeenth-century work we can also observe a desire to diversify the action, increasing the number of comedy heroes and verbal jokes. In these jokes there is a play on words, funny associations, paronymity and ambivalence of meanings. In the Baroque drama the number of means and ways of expressing comedy has also increased, e.g. we observe language parodies absent from the sixteenth-century text, unusual concepts and arguments of stage characters based on absurdity. Moreover, the anonymous seventeenth-century author used literary irony in his text (in the "sophist's" utterance) as a separate means of provoking comedy.

The contrast of those two "carnival" shows originating from two old-Polish literary periods — the Renaissance and the Baroque, is a testimony to the development and transformation of the "tragicomedy" genre. 